\title{
Skin Sarcomatoid Basal Cell Carcinoma
}

National Cancer Institute

\section{Source}

National Cancer Institute. Skin Sarcomatoid Basal Cell Carcinoma. NCI Thesaurus. Code C38111.

A basal cell carcinoma of the skin characterized by the presence of sarcomatoid features. 